\title{
Changes in the glacier extent and surface elevation in Xiongcaigangri region, Southern Karakoram Mountains, China
}

\author{
Zhiguo Li ${ }^{\text {a, b, }{ }^{*} \text {, Haiyan Fang }}{ }^{\text {, }}$, Lide Tian ${ }^{\mathrm{b}}$, Yufeng Dai ${ }^{\mathrm{b}}$, Jibiao Zong ${ }^{\mathrm{b}}$ \\ a College of Environment and Planning, Shangqiu Normal University, Shangqiu 476000, China \\ ${ }^{\mathrm{b}}$ Institute of Tibetan Plateau Research, Chinese Academy of Sciences, Beijing, China \\ c Institute of Geographic Sciences and Natural Resources Research, Chinese Academy of Sciences, Beijing, China
}

\section{A R T I C L E I N F O}

\section{Article history:}

Available online 29 December 2014

\section{Keywords:}

Glacier variations

Remote sensing

Southern Karakoram

Xiongcaigangri region

\begin{abstract}
A B S T R A C T
The recent evolution of the Karakoram glaciers, widely acknowledged as peculiar, remains poorly understood. The Xiongcaigangri region is in the south of Karakoram, and its glacial melt water has a significant impact on the local water supply and ecosystem. In this work, glacial changes in the Xiongcaigangri region were detected based on topographic maps and Landsat MSS/TM/ETM+/OLI, SRTM4.1 DEM and Glas/ICESat remote sensing data and GIS techniques. The results show that from 1968 to 2013 , the total glacier area decreased from $181.10 \mathrm{~km}^{2}$ to $178.47 \mathrm{~km}^{2}$, an overall loss of $2.63 \mathrm{~km}^{2}$, or $1.45 \%$ of the entire 1968 glacial area. The inverse relationship between the retreating area and the change rate indicates that small glaciers may be retreating faster. The main glacial melting occurred below $6500 \mathrm{~m}$ a.s.l, and the reduction of $2.62 \mathrm{~km}^{2}$ accounts for $99.62 \%$ of the total glacial retreat in the area studied. The very slight reduction of $0.01 \mathrm{~km}^{2}$ over $6500 \mathrm{~m}$ a.s.l accounts for only for $0.38 \%$ of the total glacial retreat in the area studied. The results also show that the glacier areas are decreasing on all slopes, and larger area losses have been observed on smaller slopes, whereas smaller area losses have been observed on the larger slopes. The different aspects of the study all showed glacier retreat taking place between the period from 1968 to 2013. The largest area decrease is in west, and the area lost in the other aspect was comparatively small. Total glacier mass loss in the Xiongcaigangri region is estimated to be $(10.97 \pm 22.39) 10^{8} \mathrm{~m}^{3}$ w.e. between 1968 and 2000. The average elevation loss estimated from the ICESat and 2000 SRTM difference was from $-4.69-3.40 \mathrm{~m}$ per year, and the average elevation loss between SRTM and 1968DEM was from -0.92 to $0.66 \mathrm{~m}$ per year. Increasing temperatures along with decreasing precipitation was determined to be the primary factor driving the glacier retreat in the Xiongcaigangri region.
\end{abstract}

() 2014 Elsevier Ltd and INQUA. All rights reserved.

\section{Introduction}

Global climate change and its impact have jointly become major concerns for governments, scientists and policy makers. The globally averaged combined land and ocean surface temperature data shows a warming of $0.85 \mathrm{C}^{\circ}$ over the period from 1880 to 2012 (IPCC, 2013). Glaciers are sensitive to temperature changes and are regarded as indicators of climate change. Global warming has caused the majority of glaciers to enter a state of retreat in the last 100 years. This trend has accelerating in recent decades (with losses

\footnotetext{
* Corresponding author. College of Environment and Planning, Shangqiu Normal University, Shangqiu 476000, China.

E-mail address: lizhiguo999999@163.com (Z. Li).
}

measured by length, area or volume). The data from the 21st century is most significant (Dyurgerov and Meier, 2000; IPCC, 2013). Despite the large amount of ice stored in the polar ice caps, the loss of mountain glaciers and ice caps have had an important impact on sea level rise over the past decades and will affect this phenomenon a century in the future, in addition to affecting regional water cycles and water resource accessibility (Immerzeel et al., 2010; Kaser et al., 2010; Radić and Hock, 2011; IPCC, 2013).

The Tibetan Plateau (TBP) and its surroundings contain the largest number of glaciers outside the Polar Regions (Yao, 2008) and is known as the world's "third pole". Glacial changes in the TBP and its surroundings not only lead to changes in atmospheric circulation patterns in the region and the northern hemisphere (Qiu, 2008) but also affect agriculture, power generation and the water supplies of 1.5 billion people in the surrounding areas 
across ten countries (Immerzeel et al., 2010; Piao et al., 2010; Qiu, 2010). Hence, the state of the TBP glaciers has attracted attention worldwide. These glaciers are largely retreating (Qiu, 2010), but some of the glaciers in the Karakorum Mountains actually are stable or advancing (Bolch et al., 2012; Yao et al., 2012; Gardner et al., 2013; IPCC, 2013; Neckel et al., 2014). This is peculiar, but the causes and mechanisms behind these abnormal changes are poorly understood. Moreover, the retreat of glaciers is leading to increases in the levels of many inland lakes, causing flooding in pastures and ecological and environmental changes, which affect farmers and herdsmen in the areas surrounding the TBP (Yao, 2010). Thus, research on the changes in the Karakorum glaciers have important scientific significance and will improve the understanding of the Karakoram Mountain's environmental changes and their response to global change. Additionally, this research can help provide information on the water volume changes in surrounding inland lakes, which is important to developing response measures for production losses and preserving the living conditions of local farmers and herdsmen. Although some research has been previously carried out (Gardner et al., 2013; Neckel et al., 2014), the glacier changes in the Xiongcaigangri region of the Southern Karakoram Mountains, located at the transition zone of the Karakoram-Himalaya region, are poorly understood. In this study, we focus on glacier area trends and the elevation changes over the period from 1968 to 2013 and the reasons behind these changes.

\section{Study area}

The Xiongcaigangri region is located in Southern Karakoram Mountains, which is on the northwestern part of the TBP (see Fig. 1a). The climate in the Karakoram Mountains is influenced by Asian monsoons and westerly cyclones, and the local glaciers are classified as continental-type glaciers (Shi, 2008). The Asian monsoons contribute $80 \%$ of the summer precipitation in the southeastern part of the Karakoram Range and predominantly result from westerly cyclones, which are responsible for about two thirds of the snowfall at high altitudes in the winter (Bolch et al., 2012).

The mean equilibrium line attitude (ELA) in the Xiongcaigangri Mountains is approximately $6000 \mathrm{~m}$ a.s.l (Shi, 2008). The mean annual air temperature and the annual mean precipitation from 1961 to 2013 were approximately $0.71{ }^{\circ} \mathrm{C}$ and $70.60 \mathrm{~mm}$ at Shiquanhe meteorological station $\left(32^{\circ} 30^{\prime} \mathrm{N}, 80^{\circ} 08^{\prime} \mathrm{E}, 2924 \mathrm{~m}\right.$ a.s.l), respectively.

\section{Data and methods}

\subsection{Remote sensing data}

A total of 12 topographic maps (1: 50 000) were used in this study. These maps were acquired in 1968 and derived from aerial photographs taken by the State Bureau of Surveying and Mapping. The maps were scanned and rectified to the Universal Transverse Mercator (UTM) coordinate system and the World Geodetic System 1984 ellipsoidal elevation (WGS84) using kilo-grids with a rootmean-square error (RMSE) less than $2 \mathrm{~m}$ in both the $\mathrm{x}$ and $\mathrm{y}$ directions. Then, $10 \mathrm{~m}$ interval contours and spot heights were digitized to generate a Triangular Irregular Networks (TIN) map and create a digital elevation model (DEM) (hereinafter referred to as 1968DEM). The result of the processing method using the kilo-grids is better than the seven parameter transformation method, in which the error of datum transformation is $<0.002 \mathrm{~m}$ (Wang et al., 2003). The glacier parameters (area, elevation, slope and aspect) were obtained from the 1968DEM.

The Landsat MSS/TM/ETM+/OLI remote sensing data (shown in Table 1) were employed to monitor the extent of the glacier change. The cloud coverage of the images in Table 1 is less than $1 \%$. Moreover, the cloud obscuration had little impact on the glacial outline delineation for all of the glaciers collectively distributed, and there is little cloud coverage on top of all of the glaciers, although there may have been clouds in other places outside of the study area. All

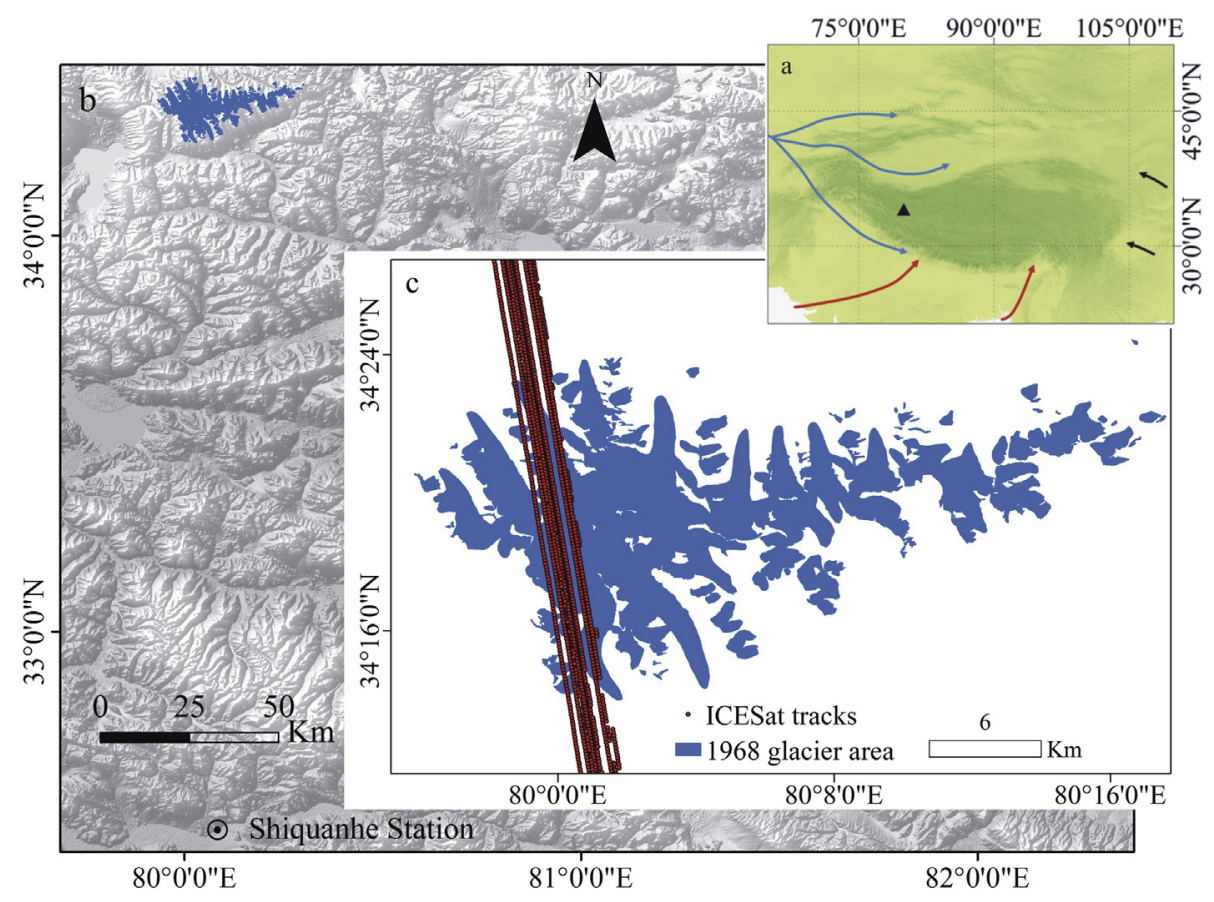

Fig. 1. Location of the glaciers in the Xiongcaigangri Mountains. 
of the remote sensing images chosen were taken within the same month and show very little snow cover, and two or three other images taken at nearly the same time are chosen as reference data to help determine the seasonal snow cover. The uncertainty in the glacier boundary delineation caused by clouds and seasonal snow cover was reduced as much as possible through the images and reference data that were chosen and applied. Landsat images are provided by the US Geological Survey (USGS; http://glovis.usgs. gov) and the Global Land Cover Facility. The image data were orthorectified to the WGS84 UTM datum. The Landsat images were geo-corrected and co-registered by the previously processed topographic maps using an RMSE value of less than $14.25 \mathrm{~m}$ in both the $\mathrm{x}$ and $\mathrm{y}$ directions with 18 points. Manual digitization was used, as recommended by Raup et al. (2007) as the best tool to extract more reliable information from satellite images for glacier boundary extraction.

Table 1

Sources of data used for this study.

\begin{tabular}{|c|c|c|c|c|}
\hline Data source & Acquisition date & Path, row & $\begin{array}{l}\text { Image } \\
\text { resolution }(\mathrm{m})\end{array}$ & $\begin{array}{l}\text { DEM } \\
\text { error }(\mathrm{m})\end{array}$ \\
\hline $\begin{array}{l}\text { Topographic } \\
\text { map }\end{array}$ & Sep 1968 & & 5 & 10 \\
\hline Landsat MSS & 01 Nov 1976 & Path 157 Row 36 & 57 & \\
\hline Landsat TM & 17 Oct 1991 & Path 145 Row36 & 28.5 & \\
\hline Landsat ETM+ & 20 Oct 2001 & Path 145 Row 36 & 28.5 & \\
\hline Landsat 8 OLI & 01 Aug 2013 & Path 146 Row 36 & 28.5 & \\
\hline SRTM & $\begin{array}{l}11 \text { to } 22 \\
\text { Feb } 2000\end{array}$ & & 90 & 16 \\
\hline ICESat GLA14 & $\begin{array}{l}25 \text { Oct } 2003 \\
\text { to } 09 \text { Oct } 2009\end{array}$ & & 65 & 0.10 \\
\hline
\end{tabular}

in the study region during the 2003-2009 period was downloaded from the U.S. National Snow and Ice Data Center (NSIDC, http://nsidc.org/data/icesat/data.html). The raw data were processed into elevation data by a conversion program provided by NSIDC. Then, the processed GLAS elevations are converted from Topex/Poseidon ellipsoid and EGM96 Geoid to the WGS84 ellipsoid elevations by the formula proposed by Zhang et al. (2011):

ICESat elevation $=$ ICESat elevation measured - ICESat geoid -0.7 .

ICESat measurements were excluded from the analysis if the difference between the ICESat and SRTM elevations exceeded $150 \mathrm{~m}$ (Neckel et al., 2014).

The SRTMDEM was geo-corrected and co-registered by 1968DEM with a RMSE less than $45 \mathrm{~m}$ in both the $\mathrm{x}$ and $\mathrm{y}$ directions before being re-sampled to a $10 \mathrm{~m}$ interval (SRTMDEMP). The glacier volume or surface elevation changes derived from comparisons of the 1968DEM, SRTMDEMP and ICESat elevation data for different years. The glacier ice volume changes between the 1968DEM and SRTMDEMP data were calculated by multiplying the mean value of the surface elevation change and the glacier surface area in 1968. To convert a volume change into a mass change, a density of $900 \mathrm{~kg} \mathrm{~m}^{-3}$ was assumed. The glacier surface elevation changes were also estimated wherever ICESat elevation data are available. The ICESat footprints distribution on Xiongcaigangri glaciers are shown in Table 2.

Table 2

ICESat glacier footprints in Xiongcaigangri region.

\begin{tabular}{|c|c|c|c|c|c|c|c|c|c|c|c|}
\hline \multirow[t]{2}{*}{ Name } & \multirow[t]{2}{*}{ 1968Area $\left(\mathrm{km}^{2}\right)$} & \multirow[t]{2}{*}{ Slope $\left({ }^{\circ}\right)$} & \multirow[t]{2}{*}{ Aspect } & \multirow[t]{2}{*}{ Elevation ranges $(\mathrm{m})$} & \multicolumn{6}{|c|}{ Point number in different elevation intervals ( $\mathrm{m}$ ) } & \multirow[t]{2}{*}{ Sum } \\
\hline & & & & & $5399-5600$ & $5600-5800$ & $5800-6000$ & $6000-6200$ & $6200-6400$ & $6400-6600$ & \\
\hline a & 22.11 & 8.74 & SE & $5400.46-6539.46$ & 0 & 0 & 0 & 1 & 100 & 1 & 102 \\
\hline b & 13.8 & 9.22 & $\mathrm{~S}$ & $5539.88-6519.68$ & 0 & 5 & 50 & 67 & 110 & 2 & 234 \\
\hline c & 0.09 & 30.22 & $\mathrm{NE}$ & $5892.63-6161.38$ & 0 & 0 & 2 & 2 & 0 & 0 & 4 \\
\hline d & 0.73 & 18.67 & $\mathrm{NE}$ & $5946.39-6384.12$ & 0 & 0 & 5 & 11 & 1 & 0 & 17 \\
\hline e & 0.59 & 24.88 & $\mathrm{E}$ & $5884.70-6414.62$ & 0 & 0 & 5 & 3 & 0 & 0 & 8 \\
\hline $\mathrm{f}$ & 0.09 & 22.71 & $\mathrm{~S}$ & $6200.26-6364.86$ & 0 & 0 & 0 & 0 & 1 & 0 & 1 \\
\hline g & 0.91 & 26.09 & SE & $5949.27-6456.73$ & 0 & 0 & 0 & 13 & 21 & 1 & 35 \\
\hline h & 0.82 & 21.76 & W & $5958.50-6447.97$ & 0 & 0 & 0 & 0 & 6 & 1 & 7 \\
\hline $\mathrm{i}$ & 10.14 & 12.71 & $S$ & $5480.83-6441.60$ & 0 & 0 & 0 & 6 & 6 & 0 & 12 \\
\hline $\mathrm{j}$ & 14.91 & 10.6 & SW & $5428.65-6442.13$ & 13 & 67 & 94 & 131 & 59 & 1 & 365 \\
\hline $\mathrm{k}$ & 0.19 & 34.92 & $\mathrm{E}$ & $5886.72-6320.62$ & 0 & 0 & 2 & 1 & 0 & 0 & 3 \\
\hline 1 & 0.44 & 25.01 & $\mathrm{E}$ & $5823.92-6244.03$ & 0 & 0 & 0 & 2 & 1 & 0 & 3 \\
\hline \multicolumn{5}{|c|}{ Total sum } & 13 & 72 & 158 & 237 & 305 & 6 & 791 \\
\hline
\end{tabular}

The DEM acquired by the Shuttle Radar Topography Mission (SRTM) in February 2000 was one of the available DEMs that can be utilized to calculate the glacier surface elevation changes. The SRTM Version 4.1, whose study area data gaps had been processed (Reuter et al., 2007), was obtained from CSI-CGIAR (http://srtm.csi.cgiar.org/) and used to calculate the glacier volume changes and surface elevation change. The Ice, Cloud and Land Elevation Satellite (ICESat) was launched in 2003 and now is widely used to calculate glaciers volume changes (Kääb et al., 2012; Pieczonka et al., 2013; Neckel et al., 2014) and lake level changes (Zhang et al., 2011, 2013) on the TBP. The GLA 14 product
The elevation difference $\Delta H_{\text {ICEsat-2000 }}$ between each ICESat footprint and the SRTMPDEM was calculated by:

$\Delta \mathrm{H}_{\text {ICEsat }-2000}=\mathrm{H}_{\text {ICESat }}-\mathrm{H}_{\text {SRTMDEMP }}$,

where $\mathrm{H}_{\text {ICESat }}$ and $\mathrm{H}_{\text {SRTMDEMP }}$ are the elevation measurements from both datasets.

The elevation difference $\Delta \mathrm{H}_{2000-1968}$ between the SRTMPDEM and 1968DEM data at each ICESat footprint was calculated by:

$\Delta \mathrm{H}_{\text {SRTMDEMP-1968DEM }}=\mathrm{H}_{\text {SRTMDEMP }}-\mathrm{H}_{1968 D E M}$, 
where $\mathrm{H}_{\text {SRTMDEMP }}$ and $\mathrm{H}_{1968 D E M}$ are the elevation measurements from both datasets.

The elevation differences between different DEMS for each Xiongcaigangri glacier were calculated by elevation ranges to provide detailed results, which may avoid the effect of location and number on the result. Then, the annual glacier surface elevation change rate was obtained by $\Delta \mathrm{H}_{\text {ICEsat }-2000}$ and $\Delta \mathrm{H}_{\text {SRTMDEMP }-1968 D E M}$ divided the time interval, which is expressed in $r_{1}$ and $r_{2}$, respectively. The calculation of the $\Delta H$ trend was shown only for the glacier areas, with the non-glacier area excluded for political reasons.

\subsection{Meteorological data}

There are no weather stations located in the study area. The nearest station was the Shiquanhe station, which is located $200 \mathrm{~km}$ away from the Xiongcaigangri region. The meteorological data from Shiquanhe station were downloaded from the China Meteorological Data Sharing Service System (http://cdc.cma.gov.cn) and used to analyze climate changes and reasons for changes in the state of the glaciers from 1968 to 2013.

\subsection{Precision evaluation}

The glacier changes in the Xiongcaigangri region mainly occurred in the glacier terminus, and no obvious changes were found in the other regions. This study focused on the evolution (retreat and advance) of the glacial front, so the error estimation method of image co-registration was used in the same way as in previous research (Ye et al., 2006; Cao et al., 2014; Wang et al., 2014). The errors extracted from multi-temporal satellite images mainly result from the sensor resolution, the co-registration errors and the boundary delineation. The first two types of errors can be evaluated using a remote sensing uncertainty evaluation formula (Ye et al., 2006). The linear uncertainty can be expressed as:

$U_{L}=\sqrt{\sum \lambda^{2}}+\sqrt{\sum \sigma^{2}}$

where $U_{L}$ is the measurement uncertainty of the glacier terminus in the study area, $\lambda$ is the original pixel resolution of each image and $\sigma$ is the co-registration error of each image to the topographic map of 1968.

The area uncertainty between the multiple remote sensing data can be expressed as:

$U_{A}=\sum \lambda^{2} * \frac{2 * U_{L}}{\sqrt{\sum \lambda^{2}}}+\sum \sigma^{2}$

where UA is the measurement uncertainty of the glacier area and UL is the linear uncertainty.

The uncertainty of the glacier terminus and the area measured in this study can be calculated using Equations (3.4) and (3.5). The results are shown in Table 3.

Table 3

Uncertainty analysis between data from different eras.

\begin{tabular}{llll}
\hline Periods & Data & $\begin{array}{l}\text { Linear } \\
\text { uncertainty }(\mathrm{m})\end{array}$ & $\begin{array}{l}\text { Area } \\
\text { uncertainty } \\
\left(\mathrm{km}^{2}\right)\end{array}$ \\
\hline $1968-1976$ & Topographic map-Landsat MSS & 62.74 & 0.007 \\
$1968-1976$ & Landsat MSS-Landsat TM & 70.27 & 0.009 \\
$1991-2001$ & Landsat TM-Landsat ETM+ & 45.64 & 0.004 \\
$2001-2013$ & Landsat ETM+-Landsat 8 OLI & 45.64 & 0.004 \\
\hline
\end{tabular}

The glacial delineation error is mainly due to the experience of the operator, who delineated the glacier boundary with respect to such factors as classifying shadowed areas as perennial or seasonal snow (Xiang et al., 2014). To estimate the glacial terminus change delineation error, the glacial terminus change between the 2013 Landsat images and the 1968 topographic maps was delineated by two other colleagues, and the glacial terminus change differences between the three operators were within $3 \%$. The glacial terminus change error caused by image quality, which is affected by seasonal snow and shadow, was less than $2 \%$ based on tests and analysis.

The vertical error of the 1968DEM and SRTM data was approximately 19 m, as calculated by Equation (3.6) (Barrand et al., 2010)

Error $=\sqrt[2]{\text { Error }_{D E M 1968}^{2}+\text { Error }_{\text {SRTM }}^{2}} \approx 19 \mathrm{~m}$.

\section{Results}

\subsection{The overall glacier area change in the Xiongcaigangri region}

The glacial area extent and variations are summarized in Table 4. The glacier area in the study site decreased from $181.10 \mathrm{~km}^{2}$ in 1968 to $178.47 \mathrm{~km}^{2}$ in 2013 , corresponding to a loss of $2.63 \mathrm{~km}^{2}$. The average observed decrease of the glacier area of $0.03 \%$ per year indicates that the glaciers are not retreating rapidly. The mean area shrinkage rate was unsteady and varied over different periods, such as being relatively larger from 2001 to $2013\left(0.06 \% \mathrm{a}^{-1}\right)$. Moreover, two small glaciers with areas of $0.02 \mathrm{~km}^{2}$ both disappeared from 1968 to 2013.

Table 4

Glacier area variation in the Xiongcaigangri region from 1968 to 2013.

\begin{tabular}{|c|c|c|c|c|c|c|}
\hline \multirow[t]{2}{*}{ Date } & \multirow{2}{*}{$\begin{array}{l}\text { Area } \\
\left(\mathrm{km}^{2}\right)\end{array}$} & \multicolumn{3}{|c|}{ Period and area change } & \multicolumn{2}{|l|}{ Area change } \\
\hline & & Period & $\begin{array}{l}\text { Area } \\
\text { change }\left(\mathrm{km}^{2}\right)\end{array}$ & $\begin{array}{l}\text { Mean rate } \\
\left(\mathrm{km}^{2} \mathrm{a}^{-1}\right)\end{array}$ & Percentage (\%) & $\begin{array}{l}\text { Mean } \\
\text { rate }\end{array}$ \\
\hline 1968 & 181.10 & & & & & \\
\hline 1976 & 181.04 & 1968-1976 & -0.06 & -0.0078 & -0.03 & 0.004 \\
\hline 1991 & 180.16 & $1976-1991$ & -0.87 & -0.5832 & -0.48 & 0.03 \\
\hline 2001 & 179.78 & $1991-2001$ & -0.38 & -0.0382 & -0.21 & 0.02 \\
\hline 2013 & 178.47 & $2001-2013$ & -1.31 & -0.1093 & -0.72 & 0.06 \\
\hline Total & & $1968-2013$ & -2.63 & -0.0585 & -1.45 & \\
\hline
\end{tabular}

4.2. The impact of size and topographic factors on area distribution and change

The glacier size and topographic features such as altitude, slope and aspect are unique to each glacier and may affect the rate of any changes. It is true that the $2.63 \mathrm{~km}^{2}$ glacier terminus loss is not large. However, there is no provision on how much overall glacier terminus loss can make the relation analysis of areal reductions and topographic characteristics tenable. In addition, the glaciers in the debated region, Karakoram, where the glaciers are relatively stable or even advancing, contrast with other regions such as the Himalayas. Here, we show just one of the possible results of scientific research. In this section, the rates of shrinkage are analyzed for different size classes, glacier altitudes, slope angles and orientations from 1968 to 2013.

The 154 glaciers in Xiongcaigangri region are divided into seven classes according to their 1968 area. The number, area and percent change of each class were examined to investigate glacier changes (see Fig. 2). The analysis shows that small glaciers make up a large proportion of the total number. The number of glaciers with an area $<1 \mathrm{~km}^{2}$ was 123 , which accounted for $80.5 \%$ of the total number of 
glaciers and $15.9 \%$ of the total area. The number of glaciers with an area $>1 \mathrm{~km}^{2}$ was 30 , which accounted for $19.5 \%$ of the total number of glaciers and $84.1 \%$ of the total area. Only nine glaciers possessed an area greater than $5 \mathrm{~km}^{2}$, which accounted for $5.9 \%$ of the total of number of glaciers and $58 \%$ of the total area. Statistics of the glacier area decrease versus the size class exhibits an inverse relationship (see Fig. 2), implying that small glaciers receded faster and were more sensitive to the effects of climate change.

The glacier area distribution was divided into six elevation gradients of $200 \mathrm{~m}$ according to the 1:50 000 DEM. Then, the glacier area change was examined based on these gradients (see Fig. 3). The results show that the distribution of the glacier area increased to a maximum at $6000-6200 \mathrm{~m}$ and then decreased. There are $167.26 \mathrm{~km}^{2}$ of glacier area distributed in three elevation gradients between $5800 \mathrm{~m}$ and $6400 \mathrm{~m}$, which accounted for $92.3 \%$ of the total area. The glacier area in the other three gradients was only $13.84 \mathrm{~km}^{2}$, which accounted for $7.7 \%$ of the total area. This glacier area distribution reflects the combined effects of precipitation and terrain on glacier development. The glacier area decrease, which was $2.44 \mathrm{~km}^{2}$ and accounted for $92.8 \%$ of the total glacier area lost from 1968 to 2013, mainly occurred under $6200 \mathrm{~m}$ a.s.l. The glacier area at elevations greater than $6200 \mathrm{~m}$ showed little shrinkage. The retreat rate from 1976 to 1991 is larger than that from 1968 to 1976 and 1991 to 2001, with the exception of the retreat rate of 2001-2013. The shrinkage areas from 1976 to 1991 and 2001 to 2013 were compared over the six elevation gradients. The results showed that the decreases in area occurred at elevations greater than $5399 \mathrm{~m}-5600 \mathrm{~m}$, $5600 \mathrm{~m}-5800 \mathrm{~m}, 5800 \mathrm{~m}-6000 \mathrm{~m}$, indicating that shrinkage extended into high elevations.

Fig. 4 shows the number, area and percent decrease distribution at various slopes in the Xiongcaigangri region. The four intervals between $10^{\circ}$ and $30^{\circ}$ have a combined area of $159.09 \mathrm{~km}^{2}$, account for $87.9 \%$ of the total area and a total of 46 glaciers ( $29.9 \%$ of the total number). The other five intervals contain a total area of $22.1 \mathrm{~km}^{2}$, account for $12.1 \%$ of the total area and 108 glaciers (70.1\%). Glaciers on all slopes showed a decrease in the area from 1968 to 2013 (see Fig. 4). The largest area change occurred for slopes between $5^{\circ}$ and $20^{\circ}$, which exhibited a combined area reduction of $1.88 \mathrm{~km}^{2}$ (which accounted for $71.3 \%$ of the total decrease).

The glacier area distribution and decrease as a function of aspect was analyzed at $45^{\circ}$ intervals (see Fig. 5). In 1968, the number proportion of northeast, east, southeast and south aspects was

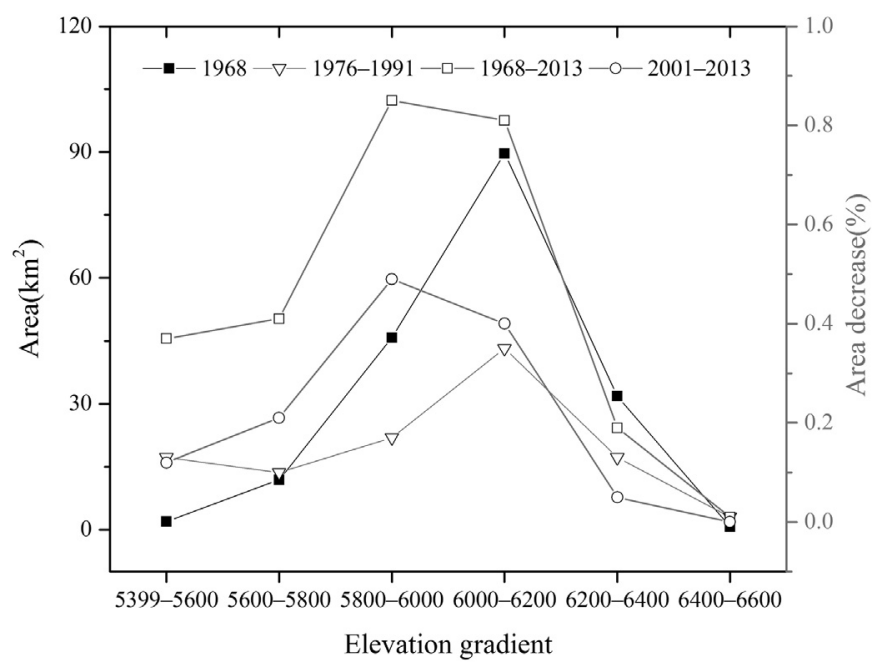

Fig. 3. Glacier area and area loss distribution versus the elevation gradient.

$>10 \%$ each, and accounted for $82.4 \%$ of the total number of glaciers; whereas the number proportion of southwest, west, northwest and north aspects was $<10 \%$ each and accounted for $18.6 \%$ of the total number of glaciers. Moreover, there is no glacier in the north aspect. The predominant aspects were east, southeast, south and southwest, which altogether accounted for $94.5 \%$ of total glacier area. The difference in glacier number and area distribution is mainly controlled by the local climate and topography effects.

The glaciers in the seven aspects have been retreating during the period from 1968 to 2013, although the rates are different (see Fig. 5). The largest area rate of decrease is in the west aspects, which have smaller average glacier areas. The largest absolute rates of change were observed in the other four aspects (east, southeast, south and southwest), with a combined reduction in area of $2.21 \mathrm{~km}^{2}$, which accounted for $84.0 \%$ of the total reduction in glacier area. Thus, the average area, the percentage of glacier area and the number of glaciers are a joint result of local climate and topography and are all impact factors.

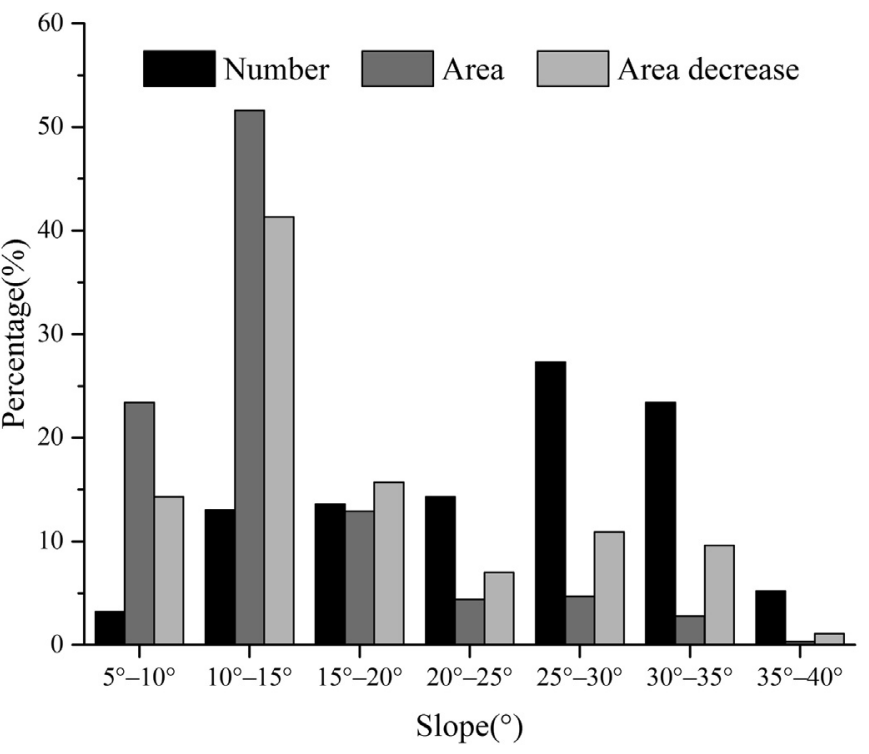

Fig. 4. Glacier number, area and decrease percent distribution versus slope.
Fig. 2. Glacier number, area distribution and percentage decrease versus size class.

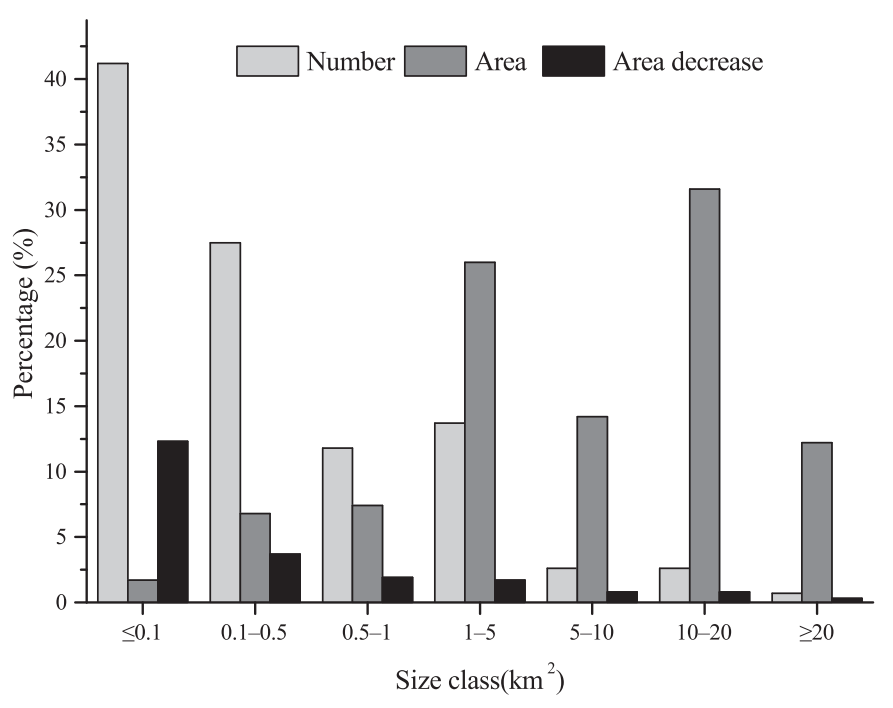




\subsection{Changes in ice volume and glacier surface elevation changes}

\subsubsection{Changes in ice volume}

From 1968 to 2000, the surface elevation difference of the Xiongcaigangri region varied from $-72 \mathrm{~m}$ to $92 \mathrm{~m}$, with a mean from the $r_{1}$ value come from just one and two footprints on glacier $b$, respectively. In addition, the absolute value of $r_{1}$ from the ICESat footprints, which is close to the edge, is usually large. This may be the result of avalanches resulting from steep terrain or strong winds.

Table 5

Average glacier surface elevation changes in the Xiongcaigangri region.

\begin{tabular}{|c|c|c|c|c|c|c|c|c|}
\hline \multirow[t]{2}{*}{ Date } & \multirow[t]{2}{*}{ ICESat point number } & \multicolumn{6}{|c|}{ Annual glacier surface elevation change rate in different elevation intervals ( $\mathrm{m} \mathrm{a}^{-1}$ ) } & \multirow[t]{2}{*}{15 day Precipitation before crossing } \\
\hline & & $5399-5600$ & $5600-5800$ & $5800-6000$ & $6000-6200$ & $6200-6400$ & $6400-6600$ & \\
\hline $10 / 25 / 2003$ & 3 & & & $3.19(-0.08)$ & $3.40(-0.24)$ & & & 0 \\
\hline $02 / 26 / 2004$ & 34 & & & $1.27(-0.15)$ & $1.46(-0.30)$ & $1.45(-0.31)$ & & 0 \\
\hline $05 / 27 / 2004$ & 65 & & $1.03(-0.05)$ & $-0.63(0.11)$ & $-1.02(-0.01)$ & $0.52(0.36)$ & & 0 \\
\hline $10 / 13 / 2004$ & 59 & $-1.91(0.05)$ & $0.84(-0.06)$ & $-1.73(0.21)$ & $-1.54(0.06)$ & $0.60(-0.10)$ & & $15 \mathrm{~mm}$ \\
\hline $05 / 29 / 2005$ & 75 & & $1.10(-0.09)$ & $0.23(0.02)$ & $-1.06(0.12)$ & $0.23(-0.33)$ & & 0 \\
\hline $10 / 30 / 2005$ & 76 & & $1.00(-0.10)$ & $1.20(-0.15)$ & $1.40(-0.22)$ & $1.55(-0.31)$ & & 0 \\
\hline $03 / 03 / 2006$ & 83 & & $0.63(-0.01)$ & $0.39(0.13)$ & $0.52(-0.02)$ & $1.22(-0.26)$ & & 0 \\
\hline $06 / 02 / 2006$ & 23 & $0.17(-0.13)$ & $1.62(-0.13)$ & $-2.56(0.67)$ & $-0.78(0.42)$ & $-0.69(0.07)$ & & $39 \mathrm{~mm}$ \\
\hline $11 / 03 / 2006$ & 59 & $-1.2(0.12)$ & & $-4.69(0.88)$ & $-0.94(0.16)$ & $0.88(-0.32)$ & $0.85(-0.44)$ & $52 \mathrm{~mm}$ \\
\hline $03 / 20 / 2007$ & 64 & $0.03(-0.09)$ & $-0.40(0.21)$ & $-2.09(0.66)$ & $-2.40(0.13)$ & $0.13(-0.29)$ & & $26 \mathrm{~mm}$ \\
\hline $10 / 11 / 2007$ & 78 & & $0.12(0.15)$ & $0.81(-0.11)$ & $0.49(-0.20)$ & $0.98(-0.34)$ & & 0 \\
\hline $02 / 26 / 2008$ & 17 & & & $0.71(-0.26)$ & $1.45(-0.32)$ & & & 0 \\
\hline $10 / 13 / 2008$ & 83 & & $0.19(-0.01)$ & $0.07(0.22)$ & $0.40(-0.04)$ & $0.74(-0.22)$ & & 0 \\
\hline $03 / 17 / 2009$ & 66 & $0.38(-0.21)$ & $0.46(-0.03)$ & $-1.67(0.43)$ & $-1.00(0.16)$ & $0.18(-0.33)$ & $1.88(-0.92)$ & 0 \\
\hline $10 / 09 / 2009$ & 6 & & & & $0.44(0.35)$ & $0.58(-0.38)$ & & 0 \\
\hline
\end{tabular}

The outside/inside brackets values correspond to the ICEsat-2000 and 2000-1968 data, respectively.

value of $-6.06 \pm 12.43 \mathrm{~m}$ (see Fig. 6). The decrease in surface elevation mainly occurred in glacier tongue regions, and the increase in the surface elevation mainly occurred in the glacier interiors. The total glacier mass loss in the Xiongcaigangri region was calculated to be $10.97 \pm 22.39 \times 10^{8} \mathrm{~m}^{3}$ w.e. between 1968 and 2000.

\subsubsection{Glacier surface elevation changes}

Table 5 provides an overview of $r_{1}$ and $r_{2}$ for different elevation intervals classified based on 1968DEM. The value of $r_{1}$ and $r_{2}$ was in the range from $-4.69-3.40 \mathrm{~m}$ and -0.92 to $0.66 \mathrm{~m}$ per year, respectively. For $r_{1}, 16$ of 44 values were negative for elevations less than $6200 \mathrm{~m}$, whereas only 1 of 15 values was negative for elevations greater than $6200 \mathrm{~m}$. The fluctuating values for $5800-6000 \mathrm{~m}$ and $6000-6200 \mathrm{~m}$ may be related to glacial movements, avalanches or accumulated snow. For $r_{2}, 37$ of 59 values were negative and 22 were positive, which accounted for $62.7 \%$ and $37.3 \%$, respectively. The area change percentages for glaciers a, b, c, d, e, f, g, h, i, j, k, 1 and $m$ were $0.31,0.45,1.3$, $1.04,0.46,1.65,0.91,0.2,0.61,0.61,0,3.47$ and 1.98 . The areas of glaciers $a, b, i$ and $j$ were more than $10 \mathrm{~km}^{2}$ each, and all exhibited insignificant area change trends. The areas of glacier $c$, $\mathrm{d}, \mathrm{e}, \mathrm{f}, \mathrm{g}, \mathrm{h}, \mathrm{k}$ and $\mathrm{l}$ were less than $1 \mathrm{~km}^{2}$, and their area change percentages were larger than that of glaciers $a, b, i$ and $j$. The total number of footprints on the four large glaciers and eight small glaciers were 713 and 78 , which made up $90.1 \%$ and $9.9 \%$ of the total, respectively. Thus, the result of the glacier surface elevation change was deeply affected by the large glaciers, and most positive values were obtained from more footprints on larger glaciers than small glaciers. On the contrary, negative values could be gained from more footprints on small glaciers than larger glaciers. The large negative values can be got if the footprints was only on small glaciers, the $-2.56,-4.69$ and $-2.09 \mathrm{~m} \mathrm{a}^{-1}$ measurements come from glacier e (two footprints), glacier 1 (two footprints) and glacier e (two footprints). Meanwhile, the rare number of ICESat footprints may cause particularity. For example, the 3.19 and $3.40 \mathrm{~m} \mathrm{a}^{-1}$ measurement

\section{Discussion}

\subsection{Glacier retreat and climate change}

The nearest Shiquanhe meteorological station, which is $200 \mathrm{~km}$ away, was used to analyze climatic trends over the last four decades because there are no meteorological stations in the study area. The precipitation and temperature data from 1968 to 2013 were collected and analyzed to explore the reasons for variations in the glaciers. The long term mean annual temperature is $0.76{ }^{\circ} \mathrm{C}$, and the long term mean annual precipitation is $71.6 \mathrm{~mm}$. Over the last 46 years, the mean annual temperature increased by $0.05 \mathrm{C}^{\circ}$ per year, whereas the mean annual precipitation at the three meteorological stations decreased by $0.42 \mathrm{~mm}$ per year (see Fig. 7). The mean annual temperature in the study area showed a significant

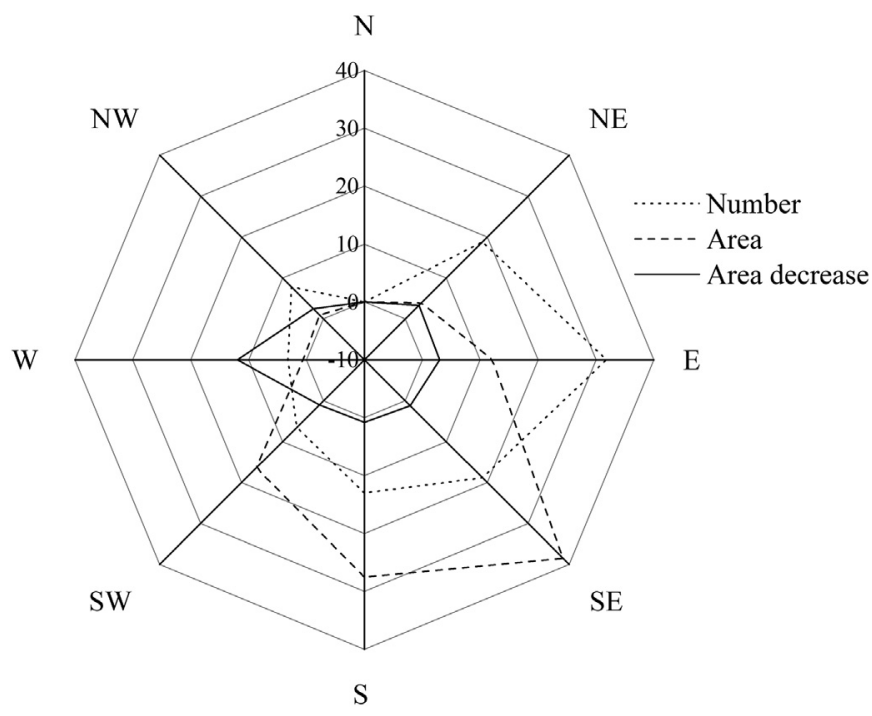

Fig. 5. Glacier number, area and area decrease percentage distribution versus aspect. 


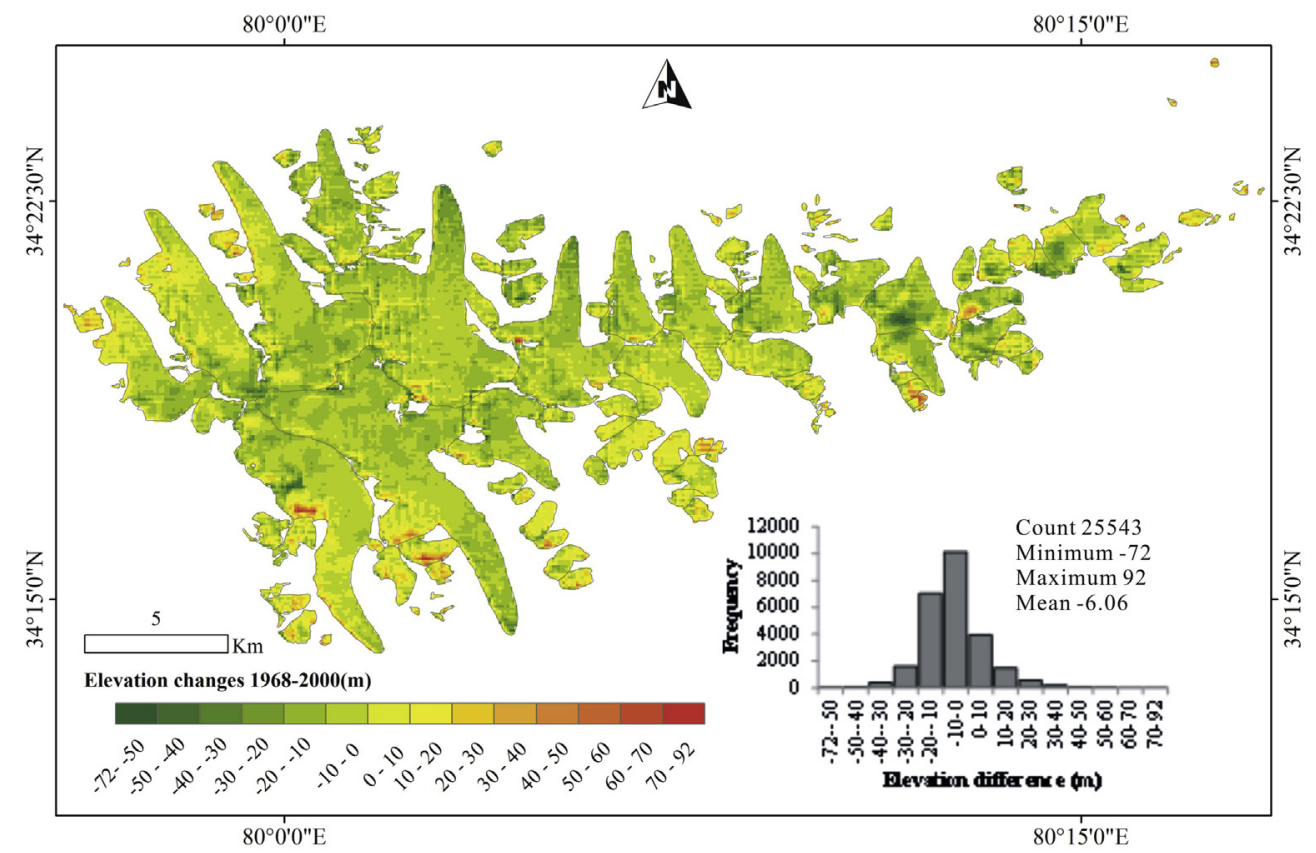

Fig. 6. Surface elevation difference in the Xiongcaigangri region between 1968 and 2000.

warming trend, and the precipitation showed a decrease in fluctuations over the last several decades. The combination of temperature and precipitation at different stages is consistent with the rate of glacial change $\left(0.004,0.03,0.02\right.$ and $\left.0.06 \mathrm{~km}^{2} \mathrm{y}^{-1}\right)$ over the past 45 years. According to Oerlemans (2005), temperature and precipitation are the meteorological elements most sensitive to glacial changes. A $1 \mathrm{C}^{\circ}$ increase in the temperature requires a $25 \%$ (Oerlemans, 2005) or 35\% (Raper et al., 2000) increase in precipitation to replenish glacier melting caused by warming. However, increasing temperatures can also change the proportion of rain and snow in the precipitation and enhance the snowmelt process on the glacier surface (Huntington, 2006), reducing the albedo, exposing more ice and promote melting. Thus, temperature plays a leading role in the impact that climate change has on the glacier mass balance. The data indicates that the air has become warmer and drier in this region, which has had a profound impact on the change in the glaciers.

\subsection{Comparison with glacier change in other areas}

To further investigate the characteristics of glacial changes in the study area, the rate of change was compared to other regions (see Fig. 8). From this, it is clear that the change in the Xiongcaigangri region is slow and the glacier area shrinkage generally decreases from the outer edge of the Himalayas to the continental interior, which coincides with previous findings (Yao et al., 2012). The main reason why the Xiongcaigangri glaciers have shrunk is due to their location. The summer Indian monsoons and the winter westerlies, combined with the huge topographic landform, exert climatic control on the glacial distribution and development on the TBP and its surroundings (Bolch et al., 2012; Yao et al., 2012; Mölg et al., 2014). The Xiongcaigangri region is located affected by a combination of Indian monsoons and winter westerlies, but is also affected by the Karakoram and Himalayan Mountains. The weakening Indian monsoon, strengthened westerlies (Yao et al., 2012) and the interplay of both circulation systems govern the mass balance. The TBP and its glaciers were found to exhibit an overall shrinking trend, with the highest shrinkage rate observed in the monsoon influenced northeastern and southeastern margins and balanced or advancing trends observed in the more westerly influenced northwestern regions (Bolch et al., 2012; Yao et al., 2012; Gardelle et al., 2013; Neckel et al., 2014). The location determined the retreat speed for the individual Xiongcaigangri glaciers. The retreating speed is less in the Indian monsoon dominated area and
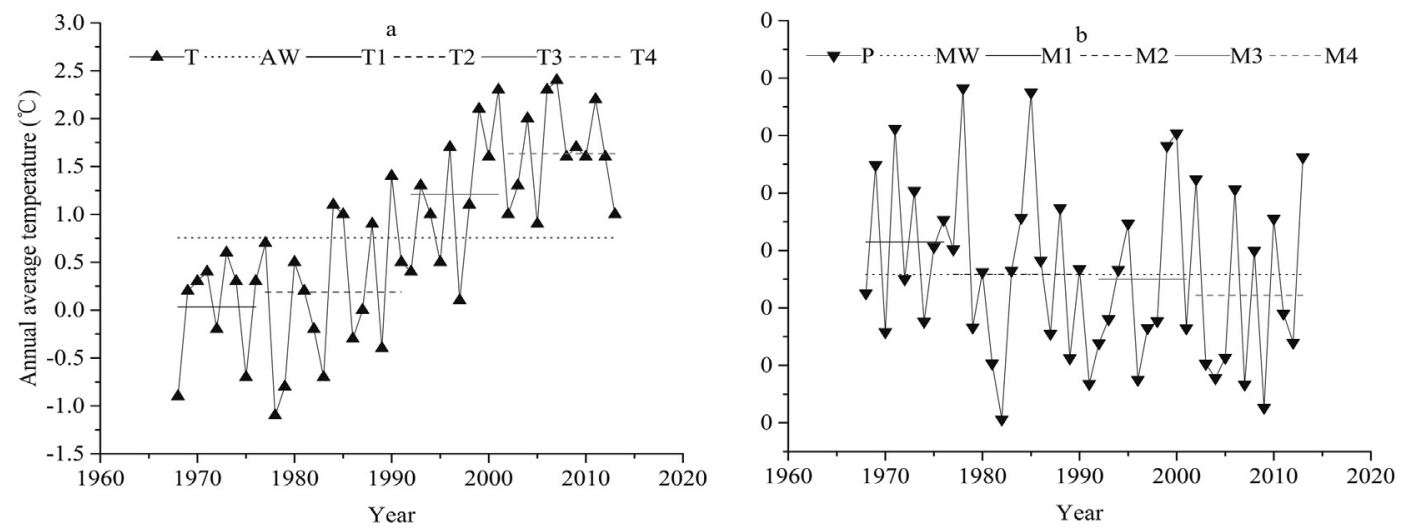

Fig. 7. Variations in the annual mean temperature and precipitation at the Shiquanhe station during the period $1968-2013$. 


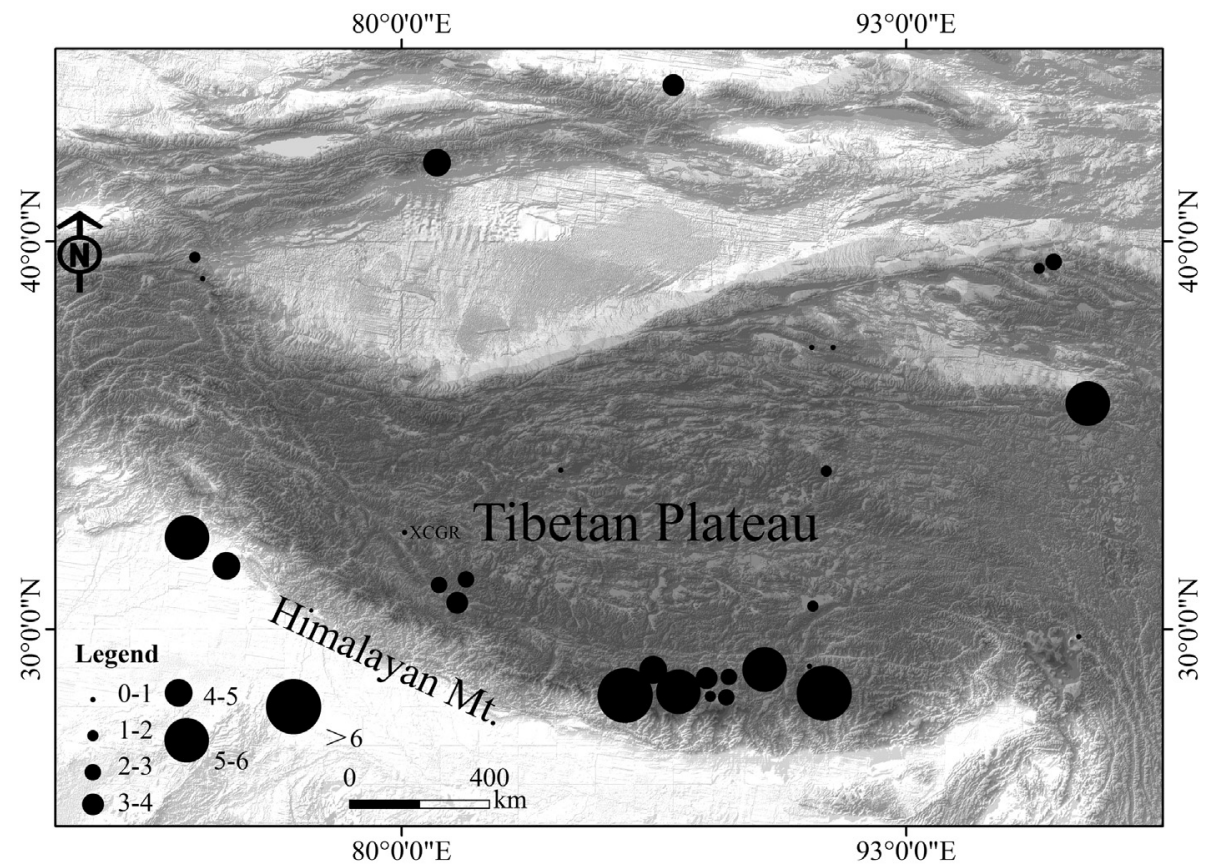

Fig. 8. Glacier area retreat rate in the Tibet Plateau and surrounding areas.

is greater in the westerly dominated area where mass gains were reported. Most Himalayan glaciers have been observed to be shrinking. The Xiongcaigangri region is located $230 \mathrm{~km}$ north of the Himalayas. Most Karakoram glaciers were found to have increased in mass and the Xiongcaigangri region is in the southern-most part of Karakoram. Moreover, the larger glaciers in this region are centrally distributed, which may produce a local environment that leads to less mass loss. The ELA in the Xiongcaigangri Mountains is approximately $6000 \mathrm{~m}$ a.s.l (Shi, 2008), which is higher than most other regions in the TBP and its surrounding. The lowest altitude of the lowest glaciers in the Xiongcaigangri and Luozha regions in the eastern Himalayas are $5399 \mathrm{~m}$ a.s.l and $4508 \mathrm{~m}$ a.s.l (Li et al., 2011), respectively. High elevation distribution may also be one of the causes of less observed shrinkage in the Xiongcaigangri glaciers.

The results of our analysis of the glacier mass gain for the Xiongcaigangri region in the southern Karakoram Mountains are in agreement with the glacier mass gain studies in the Karakoram Mountains conducted by Gardelle et al. (2013), Gardner et al. (2013) and Kääb et al. (2012) (for this study: -4.69 to $3.40 \mathrm{~m} \mathrm{y}^{-1}$, Gardelle et al. (2013): -0.12 to $+0.16 \mathrm{~m}$, Gardner et al. (2013): +0.10 $\pm 0.16 \mathrm{~m}$ w.e. ${ }^{-1}$, Kääb et al. (2012): -0.12 to $+0.25 \mathrm{mw}$.e. $\mathrm{y}^{-1}$ ). The elevation differences were spatially averaged from other works, such as Kääb et al. (2012), Gardelle et al. (2013), Gardner et al. (2013) and Neckel et al. (2014). However, the elevation differences in this study were calculated based on the 1968DEM elevation intervals and shown by the minimums and maximums. The ICESat footprints were not distributed in the large or small glaciers and the high and low elevation intervals. Thus, the averaged value may not be suitable for local cases. The -4.69 to $3.40 \mathrm{~m}$ per year elevation loss between the ICESat and SRTM data was a range, and -4.69 and 3.40 were each calculated from less than two points. This may be peculiar and it may be obscured by the characteristics of the source data (resolution, inconsistency of coordination, geographic error, etc.). In addition, the penetration of SRTM was not addressed in this study. Other studies have addressed this issue, which is another potential cause leading to the observed differences.

Moreover, the lake area in Songmuxi Co. that was fed by some of the Xiongcaigangri glaciers was $25.05 \mathrm{~km}^{2}, 25.62 \mathrm{~km}^{2}, 28.19 \mathrm{~km}^{2}$ and $32.62 \mathrm{~km}^{2}$ in 1968, 1976, 2000 and 2013, respectively (Gu 2014). The increasing lake area after 1976, the increasing temperature and the decreasing precipitation means that glacier mass loss has contributed to the volume rise in the lakes, which was another means to prove the glacier retreat.

\section{Conclusions}

In this work, topographic maps, Landsat MSS/TM/ETM+/OLI, SRTM4 DEM, Glas/ICESat remote sensing data and GIS techniques were used to interpret glacier changes that occurred over the past 45 years. The glacial area in the Xiongcaigangri region decreased during the period from 1968 to 2013. For a total of 154 glaciers investigated, a decrease was observed from $181.10 \mathrm{~km}^{2}$ in 1968 to $178.47 \mathrm{~km}^{2}$ in 2013 , an area loss of $1.45 \%$, which corresponds to $0.03 \% \mathrm{y}^{-1}$. The glaciers were divided into seven size classes to investigate glacial changes. The inverse relationship between area and rate of change indicated that small glaciers receded fastest. During the 1968-2013 period, the largest amount of glacial melting occurred below an elevation of $6500 \mathrm{~m}$ a.s.l, which corresponded to a reduction of $2.62 \mathrm{~km}^{2}$ and accounted for $99.62 \%$ of the total glacial retreat in the study area. A reduction of $0.01 \mathrm{~km}^{2}$ occurred over an elevation of $6500 \mathrm{~m}$ a.s.l, which accounted for $0.38 \%$ of the total glacial retreat in the study area. The glacial slope distribution was classified into seven $5^{\circ}$ intervals, with the larger area losses observed on the smaller slopes, whereas the smaller area losses occurred on the larger slopes. The aspect analysis shows that the glacier area of each aspect decreased over the 1968-2013 period. However the melt volume of the glaciers facing west was largest, whereas the melt volume of the glaciers on the other aspects was comparatively small. The surface elevation differences in the Xiongcaigangri region varied from $-72 \mathrm{~m}$ to $92 \mathrm{~m}$, with a mean value of $-6.06 \pm 12.43 \mathrm{~m}$ from 1968 to 2000 . According to the average elevation loss from the ICESat points, the elevation difference was -4.69 to $3.40 \mathrm{~m}$ per year between the ICESat and SRTM data and -0.92 to $0.66 \mathrm{~m}$ per year between the SRTMDEMP and 1968DEM data. The glacier shrinkage in the Xiongcaigangri region was found to be the result of increasing temperatures and decreasing precipitation. 


\section{Acknowledgments}

This work was supported by the National Natural Science Foundation of China (Nos. 41101072, 41001037, 40701036, 41101062 and 31100369). Landsat images, SRTM DEMS and ICESat GLA 14 products were provided by the USGS. Meteorological data from the Shiquanhe station were kindly provided by the China Meteorological Data Sharing Service System.

\section{References}

Barrand, N.E., James, T.D., Murray, T., 2010. Spatio-temporal variability in elevation changes of two high-Arctic valley glaciers. Journal of Glaciology 56, 771-780.

Bolch, T., Kulkarni, A., Kääb, A., Huggel, C., Paul, F., Cogley, J.G., Frey, H., Kargel, J.S. Fujita, K., Scheel, M., 2012. The state and fate of Himalayan glaciers. Science 336, $310-314$.

Cao, B., Pan, B.T., Wang, J., Shangguan, D.H., Wen, Z.L., Qi, W.T., Cui, H., Lu, Y.Y., 2014 Changes in the glacier extent and surface elevation along the Ningchan and Shuiguan river source, eastern Qilian Mountains, China. Quaternary Research $81,531-537$.

Dyurgerov, M.B., Meier, M.F., 2000. Twentieth century climate change: evidence from small glaciers. Proceedings of the National Academy of Sciences 97, 1406-1411.

Gardelle, J., Berthier, E., Arnaud, Y., Kääb, A., 2013. Region-wide glacier mass balances over the Pamir-Karakoram-Himalaya during 1999-2011. The Cryosphere 7, 1263-1286.

Gardner, A.S., Moholdt, G., Cogley, J.G., Wouters, Bert, Arendt, A.A., Wahr, J., Berthier, E., Hock, R., Pfeffer, W.T., Kaser, g., Ligtenberg, S.R.M., Bolch, T. Sharp, M.J., Hagen, J.O., van den Broeke, M.R., Paul, F., 2013. A reconciled estimate of glacier contributions to sea level rise: 2003 to 2009. Science 340 852-857.

Gu, F., 2014. Glacier and Lake Change of Songmuxi Co (Undergraduate dissertation). Shangqiu Normal University.

Huntington, T.G., 2006. Evidence for intensification of the global hydrologic cycle: review and synthesis. Journal of Hydrology 319, 83-95.

Immerzeel, W.W., van Beek, L.P.H., Bierkens, M.F.P., 2010. Climate change will affect the Asian water towers. Science 328, 1382-1385.

IPCC, 2013. Climate change 2013: the physical science basis. In: Stocker, T.F., Qin, D. Plattner, G.-K., Tignor, M., Allen, S.K., Boschung, J., Nauels, A., Xia, Y., Bex, V., Midgley (Eds.), Contribution of Working Group I to the Fifth Assessment Report of the Intergovernmental Panel on Climate Change. Cambridge University Press, Cambridge, UK.

Kääb, A., Berthier, E., Nuth, C., Gardelle, J., Arnaud, Y., 2012. Contrasting patterns of early twenty-first-century glacier mass change in the Himalayas. Nature 488 495-498.

Kaser, G., Großhauser, M., Marzeion, B., 2010. Contribution potential of glaciers to water availability in different climate regimes. Proceedings of the National Academy of Sciences 107, 20223-20227.

Li, Z.G., Yao, T.D., Ye, Q.H., Tian, L.D., Li, C.L., 2011. Monitoring glacier variations based on remote sensing in the Luozha Region, Eastern Himalayas, 1980-2007. Geographical Research 26 (5), 836-846 (in Chinese with English abstract).
Mölg, T., Maussion, F., Scherer, D., 2014. Mid-latitude westerlies as a driver of glacier variability in monsoonal High Asia. Nature Climate Change 4, 68-73.

Neckel, N., Kropáček, J., Bolch, T., Hochschild, V., 2014. Glacier mass changes on the Tibetan Plateau 2003-2009 derived from ICESat laser altimetry measurements. Environmental Research Letters 9 (1), 014009.

Oerlemans, J., 2005. Extracting a climate signal from 169 glacier records. Science 308, 675-677.

Piao, S., Ciais, P., Huang, Y., Shen, Z.H., Peng, S.S., Li, J.S., Zhou, L.P., Liu, H.Y., Ma, Y.C., Ding, Y.H., Friedlingstein, P., Liu, C.Z., Tan, K., Yu, Y.Q., Zhang, T.Y., Fang, J.Y., 2010 The impacts of climate change on water resources and agriculture in China. Nature 467, 43-51.

Pieczonka, T., Bolch, T., Wei, J.F., Liu, S.Y., 2013. Heterogeneous mass loss of glaciers in the Aksu-Tarim Catchment (Central Tien Shan) revealed by $1976 \mathrm{KH}-9$ Hexagon and 2009 SPOT-5 stereo imagery. Remote Sensing of Environment $130,233-244$.

Qiu, J., 2008. The third pole. Nature 454, 393-396.

Qiu, J., 2010. Measuring the meltdown. Nature 468, 141-142.

Radić, V., Hock, R., 2011. Regionally differentiated contribution of mountain glaciers and ice caps to future sea-level rise. Nature Geoscience 4, 91-94.

Raper, S.C.B., Brown, O., Braithwaite, R.J., 2000. A geometric glacier model for sealevel change calculations. Journal of Glaciology 46, 357-368.

Raup, B.H., Kääb, A., Kargel, J.S., Bishop, M.P., Hamilton, G., Lee, E., Paul, F., Rau, F., Soltesz, D., Khalsa, S.J.S., Beedle, M., Helm, C., 2007. Remote sensing and GIS technology in the Global Land Ice Measurements from Space Project. Computers \& Geosciences 33, 104-125.

Reuter, H.I., Nelson, A., Jarvis, A., 2007. An evaluation of void filling interpolation methods for SRTM data. International Journal of Geographical Information Science 21, 983-1008.

Shi, Y.F., 2008. Concise Glacier Inventory of China. Shanghai Popular Science Press, Shanghai.

Wang, L., Li, Z.Q., Wang, F.T., Edwards, R., 2014. Glacier shrinkage in the Ebinur lake basin, Tien Shan, China, during the past 40 years. Journal of Glaciology 60, 245-254.

Wang, J., Wang, J., Lu, C., 2003. Problem of coordinate transformation between WGS-84 and BEIJING 54. Journal of Geodesy and Geodynamics 23, 70-73 (in Chinese with English abstract).

Xiang, Y., Gao, Y., Yao, T.D., 2014. Glacier change in the Poiqu River basin inferred from Landsat data from 1975 to 2010. Quaternary International 349, 392-401.

Yao, T., 2008. Map of Glaciers and Lakes on the Tibetan Plateau and the Surroundings. Xi'an Cartographic Publishing House.

Yao, T.D., 2010. Glacial fluctuations and its impacts on lakes in the southern Tibetan Plateau. Chinese Science Bulletin 55 (20), 2071.

Yao, T.D., Thompson, L., Yang, W., Yu, W.Y., Gao, Y., Guo, X.J., Yang, X.X., Duan, K.Q., Zhao, H.B., Xu, B.Q., Pu, J.C., Lu, A.X., Xiang, Y., Kattel, D.B., Joswiak, D., 2012. Different glacier status with atmospheric circulations in Tibetan Plateau and surroundings. Nature Climate Change 2, 663-667.

Ye, Q., Kang, S., Chen, F., Wang, J., 2006. Monitoring glacier variations on Geladandong mountain, central Tibetan Plateau, from 1969 to 2002 using remotesensing and GIS technologies. Journal of Glaciology 52 (179), 537-545.

Zhang, G.Q., Xie, H.J., Kang, S.C., 2011. Monitoring lake level changes on the Tibetan Plateau using ICESat altimetry data (2003-2009). Remote Sensing of Environment 115 (7), 1733-1742.

Zhang, G.Q., Yao, T.D., Xie, H.J., Kang, S.C., Lei, Y.B., 2013. Increased mass over the Tibetan Plateau: from lakes or glaciers? Geophysical Research Letters 40, $2125-2130$. 